\title{
SMOLÍK, Josef. Psychologie terorismu a radikalizace: jak se z beránků stávají vlci. Brno: Mendelova univerzita v Brně, 2020. ISBN: 978-80- 7509-723-1. $174 \mathrm{~s}$.
}

\section{Richard Stojara, Martin Doleček ${ }^{\mathrm{b}}$}

Přestože téma terorismu díky své trvalé aktuálnosti stále generuje velké množství více či méně odborné literatury, lze $v$ této záplavě nalézt i tituly, které by neměly uniknout pozornosti expertů i laické veřejnosti. Do této kategorie, která přináší nové pohledy a témata, zcela jistě patři i vědecká monografie Psychologie terorismu a radikalizace: jak se z beránků stávají vlci etablovaného odborníka na psychologii terorismu Josefa Smolíka z Mendelovy univerzity. Jeho práce shrnuje a prezentuje základní teoretické poznatky o soudobém terorismu, přičemž ústředním tématem textu je samotná cesta vedoucí jedince i skupiny k násilným aktivitám, tedy proces radikalizace konkrétních osob či skupin, které se mohou v určité fázi stát pưvodci a realizátory teroristických útoků. Monografie tak přehledně přibližuje dva vzájemně provázané jevy, tj. akt terorismu a radikalizační proces, který k němu vede. Tento proces je pak dán do kontextu s tzv. politickým násilím. Autor tak nejenže zúročuje své letité zaměření na pestrou, avšak prolínající se paletu odborných témat, ale především přináší do odborné debaty text, jenž prokazuje, že mezioborovost není pouze atraktivně znějícím pojmem.

Autor zde popisuje psychologické mechanismy, koncepty a teorie, kterými je možné fenomén terorismu objasnit či alespoň prezentovat komplikované dimenze, které v sobě obsahuje. Charakterizovány a prezentovány jsou zde i hlavní typy a subtypy terorismu, případně i vybrané strategie a taktické postupy využivané soudobými teroristickými skupinami. Hlavní pozornost je zde však věnována, jak již samotný název knihy vypovídá, procesu radikalizace. Autor zde uvádí jak teoretická východiska, tak i stručné kazuistiky vybraných jednotlivců, přičemž zde klade velký důraz na psychologické a sociologické aspekty jejich osobní radikalizace. Čtenář má tak možnost seznámit se s hlavními psychologickými mechanismy, které ovlivňují individua a vedou $\mathrm{k}$ jejich angažovanosti ve zcela extrémním a specifickém prostředí. To je minimálně v českém prostředí hlavní přidanou hodnotou této knihy, v níž se zúročuje autorova erudice a jeho dlouhodobá pozornost věnovaná právě psychologické a sociologické dimenzi při výzkumu terorismu.

Text má výrazně multidisciplinární charakter, autor zde vychází z poznatků řady vědních disciplín, mimo již uvedené a stěžejní psychologie i sociologie, politologie, kriminologie a bezpečnostních studií. Kromě samotného procesu radikalizace je zde zajímavě popsán

\footnotetext{
${ }^{a}$ Centre for Security and Military Strategic Studies, University of Defence in Brno. Czech Republic. richard.stojar@unob.cz. Researcher ID: ABF-8988-2020

${ }^{\mathrm{b}}$ Centre for Security and Military Strategic Studies, University of Defence in Brno. Czech Republic. martin.dolecek@unob.cz
} 
i proces rekrutace vhodných jednotlivců radikálními a teroristickými organizacemi. Pozornost je $v$ této části věnována i rekrutaci ve specifickém prostředí, které představují věznice a jiná detenční zařízení, v současnosti jedny $z$ hlavních náborových míst teroristických aktivistů a radikálů. $V$ rámci komplexního popisu fenoménu se autor ještě stručně pozastavuje i u problematiky financování radikálních a teroristických skupin a postupech, které mohou vést k efektivnímu působení při eliminaci těchto finančních toků. $V$ závěru knihy jsou prezentovány zahraniční zkušenosti uplatňované při prevenci procesu radikalizace i soudobé deradikalizační postupy realizované na různých úrovních.

Čtenář, který knihu vezme do ruky coby své první seznámení s touto problematikou, může být odrazen hustě navrstvenou plejádou odborných konceptů. Smolík se zde nesnaží být popularizátorem tématu, od toho slouží jiné jeho texty. Tato publikace naopak usiluje o co možná nejúplnější pokrytí fenoménu, jemuž popularizace při jeho vysvětlování mnohdy spíše škodí. Zároveň autor není pouze jakýmsi důsledným sběratelem veškerých poznatků $k$ danému tématu, které by čtenáři předhodil bez hlubšího smyslu. Představované dílo je uceleným a vytřizeným přehledem těch informací, kterými se Smolík v průběhu let důkladně zaobíral a které považuje za skutečně konstruktivní a prínosné. Drobné stř́pky v podobě kazuistik jsou pro něj podobně cenné jako velké kusy teorie. Výsledný tvar sestavuje poučeně a promyšleně $a$ vydání knihy o daném tématu je $v$ jeho podání vyzrálým aktem prezentace poměrně uceleného obrazu o fenoménu terorismu.

Monografie Josefa Smolíka představuje skutečně kvalitní a originální přínos pro poznání a pochopení fenoménu soudobého terorismu, čtenář zde rozhodně nenalezne jen recyklaci toho, s čím se můžeme $v$ textech na toto téma často setkat. Smolíkův text je rovněž mimo odborné kvality velmi čtivý a autor zde teoretický popis obohacuje i použitím zajímavých metafor a přirovnání. Snad jen v seznamu použitých zkratek pưsobí poněkud nadbytečně objasňování organizací či institucí typu ČR, EU, OSN, NATO či jevu COVID 19. Čtenář, který se $s$ touto knihou seznámí, se $v$ těchto prípadech patrně bude orientovat i bez této berličky. Drobnou vadou na jinak velmi kvalitním zpracování, je pak nepřesnost obsahu monografie, který opomíjí uvést závěrečný jmenný a věcný rejstřík, čímž pro závěrečnou část uvádí nepřesné stránkování.

$Z$ pohledu recenzentů lze rovněž zhodnotit, že přes vydatně zpracovaná témata samotného terorismu a radikalizace by si větší pokrytí zasloužila i v závěru otevřená problematika prevence radikalizace. Nejenže jde o téma aktuální, ale především velmi palčivé, které patrně ještě bude $v$ ne př́liš daleké budoucnosti přinášet nejednu výzvu jak expertům $v$ oblasti bezpečnosti, tak i reálně celému bezpečnostnímu systému. Lze však dovodit, že autor si je této skutečnosti vědom a téma zařadil spiše pro doplnění, nebot' není pochyb, že svou obsáhlostí by zcela jistě vydalo na samostatnou monografii.

Při celkovém zhodnocení př́nosu této vědecké monografie lze však nepochybně souhlasit $\mathrm{s}$ charakteristikou jednoho $\mathrm{z}$ recenzentů, předního odborníka na fenomén terorismu i radikalismu profesora Mareše, který uvádí:

"Kniha má potenciál oslovit široké spektrum čtenářu z bezpečnostních $i$ justičních složek, z žurnalistického prostředí se zájmem o problematiku militantních scén a představuje i podklad a impuls pro dalši akademické bádání voblasti radikalizace.“ 
Rozhodně lze také tuto práci mimo jím uvedené kategorie doporučit i studentům bezpečnostních studií či frekventantům vojenských kariérních kurzů. Přehlednost, komplexnost a zajímavé zpracování popisované problematiky je zde skutečně silnou stránkou této knihy. 